\title{
MENINGKATKAN KEMAMPUAN KONEKSI MATEMATIS DAN SELF-CONCEPT SISWA MELALUI PENDEKATAN SAINTIFIK PADA MATERI TRIGONOMETRI
}

\section{INCREASING THE CONNECTION ABILITY OF MATHEMATICAL AND SELF-CONCEPT STUDENTS WITH SCIENTIFIC APPROACH ON THE TRIGONOMETRY}

\author{
Yulia Rahmawati $Z^{1}$, Nanang Priatna ${ }^{2}$, Nurjanah ${ }^{3}$ \\ ${ }^{1}$ Universitas Tamansiswa Padang, yulia_rahmawatiz@unitas-pdg.ac.id \\ ${ }^{2}$ Universitas Pendidikan Indonesia, nanang_priatna@yahoo.com \\ ${ }^{3}$ Universitas Pendidikan Indonesia, nurjanahfattah@yahoo.co.id
}

\begin{abstract}
Abstrak
Penelitian ini bertujuan untuk mengetahui dan meningkatkan kemampuan koneksi matematis dan self-concept siswa SMA melalui pendekatan saintifik pada materi trigonometri. Metode yang digunakan adalah kuasi eksperimen dengan desain control group pretest-postest dan pengambilan sampel menggunakan teknik random sampling sehingga terpilih dua kelompok pada kelas X SMAN 1 Pangkalan Koto Baru. Kelompok eksperimen diberi pembelajaran melalui pendekatan saintifik (PS) sedangkan kelompok kontrol diberi pembelajaran biasa $(\mathrm{PB})$. Instrumen penelitian terdiri dari tes tertulis dan angket self-concept yang dianalisis dengan uji statistik $t$-test atau Mann Whitney. Hasil analisis menunjukkan bahwa: a) pencapaian dan peningkatan kemampuan koneksi matematis siswa melalui pembelajaran PS lebih baik dari siswa yang memperoleh PB, dan b) Self-concept matematis siswa melalui pembelajaran PS lebih baik dari siswa yang memperoleh PB.
\end{abstract}

Kata kunci: Koneksi, Self-Concept, Pendekatan Saintifik

\begin{abstract}
This study aims to determine and improve the mathematical connection ability and self-concept of SMA through a scientific approach to trigonometric material. The method used is quasiexperimental design with control group pretest-posttest and sampling using random sampling technique so that two groups were selected in class $X$ of SMAN 1 Pangkalan Koto Baru. The experimental group was given learning through a scientific approach $(P S)$ while the control group is given ordinary learning $(P B)$. The research instrument consisted of a written test and questionnaire self-concept which was analyzed by statistical t-testtest or Mann Whitney. The results of the analysis show that: a) the achievement and improvement of students mathematical connection ability through PS learning is better than students who obtain $P B$, and b) self-concept students mathematical through PS learning better than students who get PB.
\end{abstract}

Keywords: Connection, Self-Concept, Scientific Approach 


\section{PENDAHULUAN}

Matematika merupakan ilmu yang banyak digunakan sebagai sumber ilmu lainnya. Hal ini menunjukkan matematika sangat penting untuk cabang ilmu lain, sehingga matematika dipelajari dari jenjang dasar sampai perguruan tinggi. Oleh karena itu, terus dilakukan berbagai upaya untuk meningkatkan kualitas pembelajaran matematika dengan berbagai strategi agar ilmu yang disampaikan dapat dipahami siswa sehingga tujuan pembelajaran tercapai. Salah satu tujuan umum pembelajaran matematika yaitu untuk mempersiapkan siswa mampu mengaplikasikan matematika dan pola pikir matematika dalam kehidupan seharihari dan berbagai ilmu pengetahuan (Suherman et al., 2003).

Pentingnya pembelajaran matematika dijelaskan dalam National Council of Teachers of Mathematics (NCTM, 2000), salah satunya adalah belajar untuk mengaitkan ide (mathematical connection). Kemampuan koneksi matematis merupakan kemampuan siswa dalam memahami pelajaran matematika lebih lanjut. Siswa akan kesulitan dalam menyelesaikan permasalahan matematika tanpa memiliki kemampuan mengkoneksikan konsep dengan baik. Suherman (2008) yang mengatakan bahwa kemampuan koneksi matematika adalah kemampuan untuk mengaitkan konsep atau aturan matematika yang satu dengan yang lainnya, dengan bidang studi lainnya, atau dengan aplikasi pada kehidupan nyata. Suatu persoalan dapat diselesaikan siswa jika telah memahami permasalahan dan kemudian mengkoneksikannya dengan konsep atau aturan serta berpikir untuk mencari penyelesaiannya, baik itu permasalahan antar konsep atau aturan matematika, dengan bidang studi lainnya, maupun dengan permasalahan kehidupan sehari-hari. Tujuan siswa memiliki kemampuan koneksi matematis, yaitu agar siswa mampu: 1) mengenali dan menggunakan koneksi antar gagasan matematis; 2) memahami bagaimana beberapa gagasan matematis saling berhubungan dan berdasar pada satu sama lain untuk menghasilkan suatu keseluruhan yang koheren (padu); 3) mengenali dan menerapkan matematika baik di dalam maupun di luar konteks matematika (NCTM, 2000).

Ketika peneliti melakukan observasi awal dengan mewawancarai salah seorang guru matematika kelas $\mathrm{X}$ diperoleh informasi bahwa secara umum kemampuan siswa menyelesaikan soal matematika yang lebih kompleks masih kurang. Siswa masih bingung dalam penggunaan konsep atau aturan yang tepat untuk menyelesaikan suatu permasalahan matematika. Siswa cenderung mencatat atau menyalin dan menghafal rumus-rumus atau aturan-aturan matematika dengan tanpa makna dan pengertian. Hal ini sejalan dengan beberapa hasil penelitian yang menunjukkan bahwa dalam proses pembelajaran terlihat siswa masih sulit menghubungkan materi yang mereka pelajari dengan materi prasyarat yang sudah mereka kuasai, konsep-konsep yang telah dipelajari tidak bertahan lama dalam ingatan siswa akibatnya kemampuan koneksi mereka belum optimal (Linto et al., 2012). Begitu juga dengan hasil penelitian Ruspiani (Fajri et al., 2014) yang menunjukkan nilai rata-rata kemampuan koneksi matematis siswa sekolah menengah masih rendah yaitu kurang dari 60 pada skor 100 (22,2\% untuk koneksi matematika pada pokok bahasan lain, $44 \%$ untuk koneksi pada bidang studi lain, dan 67,3\% untuk koneksi dalam kehidupan sehari-hari. Selain itu, Kusmaydi (2010) menemukan bahwa: 1) kebanyakan siswa tidak mengetahui dan tidak mengerti materi mana yang ada hubungannya dengan materi yang akan dipelajari; 2) siswa sangat jarang bertanya karena belum mampu membuat pertanyaan 
tentang matematika yang dipelajari (siswa tidak dilatih bertanya); 3) masih banyak siswa yang tidak mampu menyatakan benda nyata, gambar dan diagram ke dalam ide matematika dan juga tidak mampu menyatakan peristiwa sehari-hari ke dalam bahasa atau bentuk simbol; 4) sebagian besar siswa tidak dapat menyelesaikan masalah-masalah yang berkaitan dengan dunia nyata atau masalah yang ada di sekitar siswa; dan 5) ada siswa yang mampu menyelesaikan suatu masalah matematika tetapi tidak mengerti apa yang dikerjakannya dan kurang memahami apa yang terkandung di dalamnya.

Beberapa penelitian di atas menunjukkan bahwa kemampuan koneksi matematis siswa pada sekolah menengah masih kurang sehingga kita perlu melakukan suatu upaya untuk meningkatkan kemampuan tersebut. Jika siswa sudah mampu mengkoneksikan suatu masalah ke dalam situasi lain dalam pembelajaran matematika, maka siswa tersebut sudah memaknai proses pembelajaran (Glacey dalam Nurhajati, 2014). Sehingga, pemahaman siswa tentang keterkaitan antar konsep atau ide-ide matematika akan bermanfaaat untuk kemampuan mereka menyelesaikan permasalahan matematika (Permana dan Sumarmo, 2007; Hendriana, Slamet, dan Sumarmo, 2014).

Indikator kemampuan koneksi matematis menurut Sumarmo (2010), diantaranya: 1) mencari hubungan berbagai representasi konsep dan prosedur; 2) memahami hubungan antar topik; 3) menerapkan matematika dalam bidang lain atau dalam kehidupan sehari-hari; 4) memahami representasi ekuivalen suatu konsep; 5) mencari hubungan satu prosedur dengan prosedur lainnya dalam representasi yang ekuivalen; dan 6) menerapkan hubungan antar topik matematika dan antara topik matematika dengan topik di luar matematika. Indikator kemampuan koneksi matematis yang digunakan dalam penelitian ini adalah: 1) menggunakan hubungan antar konsep dan prosedur matematika; 2) menyelesaikan suatu masalah matematika dengan mengaitkan konsep atau prosedur matematika dan menerapkannya dalam kehidupan nyata; dan 3) menyelesaikan suatu masalah matematika dengan mengaitkan konsep atau prosedur matematika dan menerapkannya dalam bidang studi lain.

Konsep pemikiran dan wawasan siswa terhadap matematika akan semakin lebih luas melalui proses koneksi matematis, tidak hanya terfokus pada topik yang sedang dipelajari. Apabila siswa memiliki wawasan yang luas, maka siswa akan memiliki kemampuan untuk menyelesaikan permasalahan matematika yang lebih kompleks. Lasmanawati (2011) mengungkapkan bahwa melalui koneksi matematis, wawasan siswa akan semakin terbuka terhadap matematika, yang kemudian akan menimbulkan sikap positif terhadap matematika.

Selain kemampuan koneksi matematis, terdapat aspek lain yang juga memberikan pengaruh yang signifikan terhadap proses pembelajaran matematika yaitu aspek psikologis. Aspek psikologis turut memberikan kontribusi terhadap keberhasilan seseorang dalam menyelesaikan tugas/soal dengan baik. Leonard dan Supardi (2010) mengatakan bahwa hasil belajar matematika siswa dipengaruhi oleh beberapa faktor, diantaranya sikap siswa pada matematika, yaitu konsep diri (self-concept) dan kecemasan siswa dalam belajar matematika.

Berhubungan dengan matematika, Ayodele (2011) mendefinisikan selfconcept sebagai cara seseorang untuk berfikir (thinks), merasakan (feels), bertindak (acts), menilai (values), dan mengevaluasi (evaluates) dirinya sendiri yang berhubungan dengan matematika. 
Beberapa gambaran karakteristik self-concept positif dan negatif dikemukan oleh Silvernail (1985) yang mengatakan bahwa Self-concept positif ditandai dengan: 1) tidak takut menghadapi situasi baru; 2) mampu mempunyai teman-teman baru; 3) mudah mengenal tugas-tugas baru; 4) mudah menyesuaikan diri pada orang-orang asing; 5) dapat bekerja sama; 6) bertanggung jawab; 7) kreatif; 8) berani mengemukakan pengalaman-pengalamannya; 9) mandiri; dan 10) pengembira. Self-concept negatif ditandai dengan: 1) menunggu keputusan dari orang lain; 2) jarang mengikuti aktivitas baru; 3) selalu bertanya dalam menilai sesuatu; 4) tidak spontan; 5) kaku terhadap barang-barang miliknya; 6) pendiam; dan 7) menghindar dan tampak frustasi. Siswa yang memiliki sikap positif terhadap matematika memiliki ciri-ciri seperti: menyenangi matematika, terlihat sungguh-sungguh dalam belajar matematika, memperhatikan guru dalam menjelaskan materi matematika, menyelesaikan tugas dengan baik dan tepat waktu, berpartisipasi aktif dalam diskusi, dan mengerjakan tugas-tugas pekerjaan rumah dengan tuntas dan selesai pada waktunya. Sedangkan, siswa yang memiliki sikap negatif terhadap matematika memiliki ciri-ciri, seperti: tidak menyenangi matematika, malas dalam belajar matematika, kurang memperhatikan guru saat menjelaskan materi matematika, jarang menyelesaikan tugas matematika, merasa cemas ketika mengikuti pelajaran matematika.

Selain itu, menurut Pudjiyogyanti (Salamor 2013), terdapat beberapa faktor yang berperan dalam perkembangan self-concept, antara lain: 1) Keadaan fisik dan penilaian orang lain mengenai keadaan fisik individu; 2) Faktor psikologis, antara lain: intelegensi, tingkat aspirasi, emosi, dan nama panggilan; 3) Faktor keluarga, antara lain: sikap orang tua, sikap saudara, status anak dalam keluarga, dan status sosial ekonomi keluarga; 4) Faktor lingkungan sekolah, meliputi: guru, siswa lain, dan kegiatan ekstrakurikuler; 5) Faktor masyarakat, antara lain: pola kebudayaan dan status sosial.

Menurut Colhoun dan Acocella (Pardede, 2008) terdapat tiga dimensi selfconcept yaitu: 1) Pengetahuan, dimensi pengetahuan (kognitif) mencakup apa yang kita tahu tentang diri kita sendiri yang akan memberi gambaran tentang diri sendiri; 2) Harapan, dimensi harapan atau diri yang dicita-citakan di masa depan; 3) Penilaian, dimensi penilaian terhadap diri kita sendiri. Berdasarkan tiga dimensi di atas, peneliti menggunakan indikator self-concept sebagai berikut: 1) Pengetahuan, mengenai apa yang siswa ketahui tentang matematika. Indikatornya adalah pandangan siswa terhadap matematika dan pandangan siswa terhadap kemampuan matematis yang dimilikinya; 2) Pengharapan, mengenai pandangan siswa tentang pembelajaran matematika yang ideal. Indikatornya adalah pandangan siswa tentang manfaat belajar matematika untuk masa yang akan datang dan pandangan siswa tentang manfaat yang diperolehnya dalam pembelajaran matematika melalui pendekatan saintifik; 3) Penilaian, seberapa besar siswa menyukai matematika. Indikatornya adalah ketertarikan siswa terhadap matematika dan ketertarikan siswa dalam mengerjakan soal-soal kemampuan koneksi matematis.

Upaya guru dalam meningkatkan kemampuan koneksi matematis dan selfconcept siswa harus dengan menggunakan berbagai strategi dalam proses pembelajaran. Pendekatan saintifik adalah salah satu bentuk pembelajaran yang diharapkan dapat meningkatkan kemampuan koneksi matematis dan self-concept siswa. Nurul (Marjan et al., 2014) menyebutkan pembelajaran saintifik adalah 
pembelajaran yang menggunakan pendekatan ilmiah, siswa berperan secara langsung menggali konsep dan prinsip selama kegiatan pembelajaran. Pendekatan saintifik pada kurikulum 2013 dalam Permendikbud nomor 81A yang diterapkan di Indonesia menjabarkan langkah-langkah pembelajaran tersebut menjadi lima yaitu: mengamati, menanya, mengumpulkan informasi/eksperimen, mengasosiaskan/ mengolah informasi, dan mengkomunikasikan. Sedangkan Kuhlthau et al. (2007) menyatakan langkah-langkah pendekatan saintifik meliputi: 1) merumuskan masalah; 2) mengajukan hipotesis; 3) mengumpulkan data; 4) mengolah dan menganalisa data; dan 5) membuat kesimpulan.

Pendekatan saintifik dalam pembelajaran matematika terdiri dari proses pengumpulan data dari percobaan, pengembangan dan penyelidikan suatu model matematika dalam bentuk representasi yang berbeda dan refleksi. Proses pembelajaran pada penelitian ini dirancang sedemikian rupa agar peserta didik secara aktif mengkonstruk konsep, hukum atau prinsip melalui tahapan-tahapan ilmiah seperti: 1) mengamati (untuk mengidentifikasi atau menemukan masalah), 2) menanya, 3) mengumpulkan data/informasi dengan berbagai teknik, 4) mengolah informasi, 5) mengkomunikasikan. Proses pembelajaran tersebut diharapkan dapat menjadi pembelajaran yang bermakna. Pembelajaran bermakna adalah pembelajaran yang mampu membawa siswa untuk memahami konsep dengan mengaitkan materi sebelumnya dengan materi baru. Sebaliknya jika informasi yang diterima tidak sesuai dengan pengetahuan yang telah ada, maka proses belajar hanya terjadi secara hafalan tanpa pengertian sehingga sukar untuk diingat kembali.

Menurut hasil penelitian Atsnan (2013); Efriana, F (2014); Prahastiwi et. al (2014); dan Rahmatudin et.al (2014), secara umum penerapan pendekatan saintifik dapat meningkatkan hasil belajar siswa. Hal ini menunjukkan bahwa dalam pembelajaran matematika, penerapan pendekatan saintifik berhasil meningkatkan hasil belajar siswa. Oleh sebab itu, peneliti berharap penerapan pendekatan saintifik ini juga dapat meningkatkan hasil belajar siswa, khususnya pada kemampuan koneksi matematis serta terbentuk self-concept matematis yang positif pada materi trigonometri.

\section{METODE PENELITIAN}

Penelitian ini merupakan penelitian Quasi Experiment. Penelitian ini dilakukan dengan cara memberikan perlakuan terhadap subjek penelitian berupa pembelajaran yang berbeda, sehingga digunakan dua kelas yaitu kelas eksperimen dan kelas kontrol. Kelas eksperimen mendapatkan pembelajaran dengan pendekatan saintifik (PS) dan kelas kontrol mendapatkan pembelajaran biasa (PB). Populasi adalah seluruh siswa kelas X di SMAN 1 Pangkalan Koto Baru tahun ajaran 2015/2016. Pengambilan sampel dilakukan secara acak (Random Sampling) yaitu siswa kelas X-2 dan X-3.

Desain penelitian ini menggunakan desain Control group pre-test-post-test (Arikunto, 2013) sebagai berikut:

\begin{tabular}{l|ccc|} 
Kelompok & Pretest & Perlakuan & Postest \\
Eksperimen & $\mathrm{O}$ & $\mathrm{X}$ & $\mathrm{O}$ \\
Kontrol & $\mathrm{O}$ & & $\mathrm{O}$ \\
\hline
\end{tabular}


Keterangan:

$\mathrm{O}=$ Pretest dan Postest kemampuan koneksi matematis

$\mathrm{X}=$ Pembelajaran PS

--- = Subjek tidak dikelompokkan secara acak

Untuk mengetahui Self-concept matematis siswa dapat diukur melalui skala self-concept berupa angket yang diberikan kepada siswa pada akhir pembelajaran sehingga dilakukan penelitian dengan desain sebagai berikut:

Kelompok
Eksperimen
Kontrol

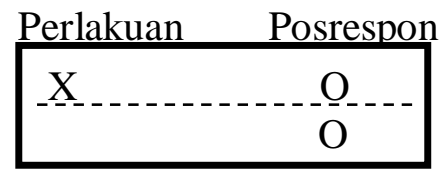

Keterangan:

$\mathrm{O}=$ Posrespon self-concept matematis siswa

$\mathrm{X}=$ Pembelajaran PS

--- = Subjek tidak dikelompokkan secara acak

Pengumpulan data dilakukan melalui tes kemampuan koneksi matematis dan angket self-concept. Tes ini bertujuan untuk mengukur kemampuan koneksi matematis siswa pada materi trigonometri. Tes yang digunakan yaitu tes pretes dan postes. Tes tersebut diberikan kepada kedua kelas sampel yaitu kelas eksperimen dan kelas kontrol. Pretes dilakukan sebelum pelaksanaan pembelajaran dalam penelitian, dan postes dilakukan setelah pembelajaran dalam penelitian selesai. Komposisi isi dan bentuk soal pretes dan postes disusun serupa dengan materi yang sama karena salah satu tujuan dari penelitian ini adalah untuk menganalisis peningkatan belajar siswa. Setiap soal disusun dalam bentuk uraian yang masing-masing kemampuan terdiri dari 4 butir soal. Tes disusun berdasarkan materi yang dipelajari siswa kelas X semester genap yaitu trigonometri. Salah satu bentuk soal yang diberikan adalah sebagai berikut.

\section{Soal}

Sebuah pesawat terbang melaju dengan kecepatan $300 \mathrm{~km} / \mathrm{jam}$ dengan arah antara arah timur dan utara, yang membentuk sudut $60^{\circ}$ terhadap arah timur. Tentukanlah berapa kecepatan pesawat pada arah: a) Timur dan b) Utara.

\section{Alternatif Jawaban:}

Ilustrasi soal:

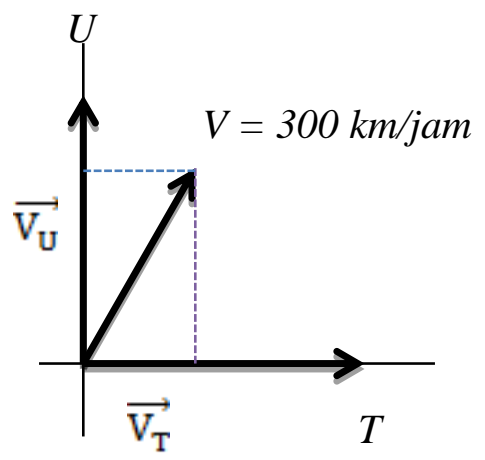


$\overrightarrow{\overrightarrow{V_{\mathrm{T}}}}=$ kecepatan pada arah timur

$\overrightarrow{\mathrm{V}_{\mathrm{U}}}=$ kecepatan pada arah utara

Berdasarkan fungsi perbandingan trigonometri, maka:

$>\sin 60^{\circ}=\frac{\overrightarrow{\mathrm{V}_{\mathrm{U}}}}{\mathrm{V}} \Leftrightarrow \overrightarrow{\mathrm{V}_{\mathrm{U}}}=\mathrm{V} \cdot \sin 60^{\circ} \Leftrightarrow \overrightarrow{\mathrm{V}_{\mathrm{U}}}=\frac{300 \mathrm{~km}}{\text { jam }} \cdot \frac{\sqrt{3}}{2}=150 \sqrt{3} \mathrm{~km} / \mathrm{jam}$

Jadi, kecepatan pesawat pada arah utara adalah $150 \sqrt{3} \mathrm{~km} / \mathrm{jam}$.

$>\cos 60^{\circ}=\frac{\overrightarrow{\mathrm{V}_{\mathrm{T}}}}{\mathrm{V}} \Leftrightarrow \overrightarrow{\mathrm{V}_{\mathrm{T}}}=\mathrm{V} \cdot \cos 60^{\circ} \Leftrightarrow \overrightarrow{\mathrm{V}_{\mathrm{T}}}=\frac{300 \mathrm{~km}}{\mathrm{jam}} \cdot \frac{1}{2}=150 \mathrm{~km} / \mathrm{jam}$

Jadi, kecepatan pesawat pada arah timur adalah $150 \mathrm{~km} / \mathrm{jam}$.

Sebelum dijadikan sebagai soal pretes dan postes, instrumen tes yang digunakan dalam penelitian ini dikonsultasikan kepada lima orang yang dianggap ahli terhadap kemampuan koneksi matematis. Para ahli tersebut terdiri atas ahli matematika, ahli evaluasi, ahli pembelajaran matematika, dan guru matematika. Selanjutnya, instrumen ini diujicobakan terlebih dahulu pada 22 orang siswa kelas XI di SMA yang menjadi tempat pengambilan data penelitian. Setelah instrumen diuji dan diberi skor sesuai kriteria pembobotan soal, selanjutnya dilakukan analisis uji instrumen untuk mengetahui validitas, reliabilitas, daya pembeda, dan indeks kesukaran dari soal.

Begitu juga dengan angket self-concept yang diberikan setelah seluruh proses pembelajaran selesai. Angket ini bertujuan untuk melihat pencapaian selfconcept siswa terhadap pembelajaran matematika khususnya pada materi trigonometri.

Menurut Arikunto (2013), validitas merupakan suatu ukuran yang menunjukan tingkatan kevalidan atau kesahihan sesuatu instrumen. Berdasarkan hasil uji coba pada siswa kelas XI, diperoleh korelasi validitas pada masingmasing butir tes kemampuan koneksi matematis dengan taraf nyata untuk nilai $t_{\text {tabel }}$ pada 0,05 dan derajat kebebasan $d k=22-2=20$ adalah 1,725 sehingga semua butir soal tes kemampuan koneksi matematis dapat dikatakan valid dengan kriteria $t_{\text {hitung }}>t_{\text {tabel }}$. Begitu juga dengan reliabilitas yang berhubungan dengan masalah kepercayaan. Suatu tes dapat dikatakan mempunyai taraf kepercayaan yang tinggi jika tes tersebut dapat memberikan hasil yang tetap. Berdasarkan hasil uji coba, diperoleh $r_{11}=0.70$ pada instrumen kemampuan koneksi matematis, sehingga dapat diinterpretasikan bahwa soal tes kemampuan koneksi matematis memiliki reliabilitas yang tinggi. Selain itu, daya pembeda tes kemampuan koneksi matematis dapat dikatakan cukup baik dan tingkat kesukaran instrumen soal termasuk ke dalam kategori mudah, sedang, dan sukar.

Sedangkan, data self-concept matematis memuat pernyataan-pernyataan menyangkut segala indikator self-concept siswa terhadap pembelajaran matematika pada materi trigonometri. Uji validitas self-concept dilakukan dengan program SPSS 16 dan $r$ tabel $=0.4227$. Banyaknya pernyataan yang digunakan untuk mengukur self-concept siswa sebanyak 17 pernyataan. Untuk mengetahui instrumen yang digunakan reliabel atau tidak, maka dilakukan pengujian reliabilitas Alpha-Cronbach. Untuk menghitung koefisien reliabilitas instrumen self-concept digunakan program SPSS, sehingga diperoleh $r_{11}=0.867$. Nilai ini 
berada pada interval $0,70<\mathrm{r}_{11} \leq 0,90$ dengan interpretasi derajat reliabilitas instrumen tinggi.

Data kemampuan koneksi matematis dan self-concept siswa dianalisis secara kuantitatif yang diawali dengan menguji persyaratan statistik yang diperlukan sebagai dasar dalam pengujian hipotesis antara lain uji normalitas, uji homogenitas. Selain dilakukan analisis secara kuantitatif, peneliti juga akan melakukan analisis secara kualitatif terhadap jawaban setiap butir soal dan pertanyaan angket self-concept. Membandingkan skor pretes dan postes untuk mencari peningkatan (gain) yang terjadi sesudah pembelajaran pada masingmasing kelas yang dihitung dengan rumus gain ternormalisasi Hake (Meltzer dalam Komala, 2012) yaitu:

$$
<g>=\frac{S_{\text {post }}-S_{\text {pre }}}{S_{\text {maks }}-S_{\text {pre }}}
$$

Keterangan:

$S_{\text {post }}:$ Skor postes

$S_{\text {pre }}:$ Skor pretes

$S_{\text {maks }}$ : Skor maksimum

Hasil perhitungan gain kemudian diinterpretasikan dengan menggunakan klasifikasi sebagai berikut:

Tabel 1. Kriteria $N$-gain

\begin{tabular}{cc}
\hline $\boldsymbol{N}$-gain & Interpretasi \\
\hline$g \geq 0,7$ & Tinggi \\
$0,3 \leq g<0,7$ & Sedang \\
$g<0,3$ & Rendah \\
\hline
\end{tabular}

\section{HASIL DAN PEMBAHASAN}

\section{Kemampuan Koneksi Matematis}

Berdasarkan analisis data pretes kemampuan koneksi matematis pada kedua kelas, tidak terdapat perbedaan antara kemampuan koneksi matematis siswa kelas PS dengan kelas PB sebelum diberikan perlakuan. Sehingga dapat dikatakan kelas PS dan PB memiliki kemampuan awal koneksi matematis yang relatif sama. Namun, setelah diberikan perlakuan PS pada kelas eksperimen dan PB pada kelas kontrol, ditinjau secara keseluruhan berdasarkan data analisis hasil penelitian diketahui bahwa pencapaian kemampuan koneksi matematis siswa yang memperoleh pembelajaran PS lebih baik dari siswa yang memperoleh PB. Hal ini ditunjukkan dari rata-rata skor postes siswa kelas PS lebih tinggi dari rataan skor postes siswa kelas PB, yaitu kelas PS 9,46 dan kelas PB 7,00. 


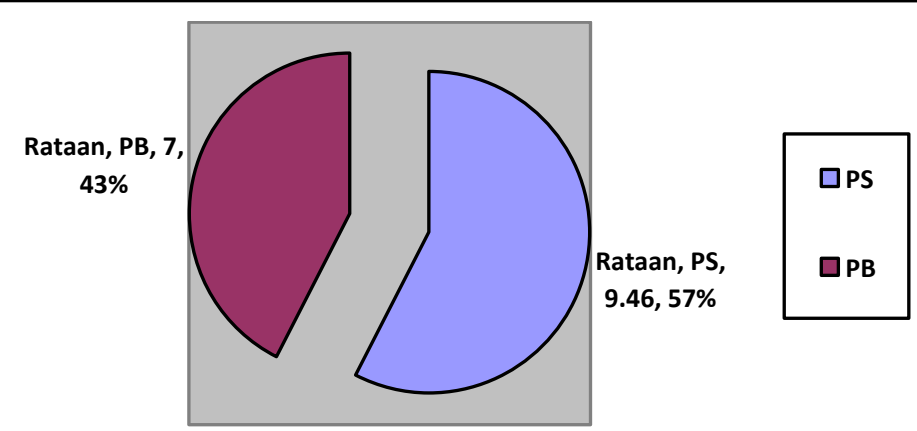

Gambar 1. Rataan skor postes siswa kelas PS dan PB

Selain itu, berdasarkan uji statistik dengan kriteria pengujian yang digunakan yaitu jika nilai sig. $(p$-value $)<\alpha(\alpha=0,05)$, maka $\mathrm{H}_{0}$ ditolak, untuk kondisi lain $\mathrm{H}_{0}$ diterima. Hasil skor postes kemampuan koneksi matematis siswa dapat dilihat pada tabel berikut.

\section{Tabel 2. Hasil Uji Mann-Whitney Skor Postes Kemampuan Koneksi} Matematis Siswa

\begin{tabular}{ccc}
\hline & Postes & Keputusan \\
\hline $\mathrm{Z}$ & -1.767 & \\
Asymp Sig (2-tailed) & 0.077 & $\mathrm{H}_{0}$ ditolak \\
Asymp Sig (1-tailed) & 0,0385 & \\
\hline
\end{tabular}

Berdasarkan hasil uji Mann Whitney skor postes diperoleh nilai sig. $(1$-tailed $)=0,0385<\alpha=0,05$ berarti $\mathrm{H}_{0}$ ditolak. Dengan demikian, disimpulkan bahwa secara signifikan pencapaian kemampuan koneksi matematis siswa yang memperoleh pembelajaran PS lebih baik dari siswa yang memperoleh PB.

Jika dilihat berdasarkan indikator kemampuan koneksi matematis pada masing-masing soal yang digunakan, yaitu: (1 dan 2) Menggunakan hubungan antar konsep dan prosedur matematika; (3) Menyelesaikan suatu masalah matematika dengan mengaitkan konsep atau prosedur matematika dan menerapkannya dalam kehidupan nyata; (4a dan 4b) Menyelesaikan suatu masalah matematika dengan mengaitkan konsep atau prosedur matematika dan menerapkannya dalam bidang studi lain, rataan skor postes siswa di kelas PS pada setiap indikator lebih tinggi dari siswa di kelas PB. Hal ini dapat dilihat pada tabel berikut.

Tabel 3. Rataan Skor Postes Kemampuan Koneksi Matematis Berdasarkan Indikator

\begin{tabular}{|c|c|c|c|c|c|c|c|}
\hline \multirow{3}{*}{ Kelas } & \multirow[b]{3}{*}{$\begin{array}{l}\text { Skor } \\
\text { Total }\end{array}$} & \multicolumn{5}{|c|}{ Indikator } & \multirow[t]{2}{*}{ Total } \\
\hline & & 1 & 2 & 3 & $4 a$ & $4 b$ & \\
\hline & & 4 & 4 & 4 & 3 & 3 & 18 \\
\hline PS & $\bar{X}$ & 2,58 & 0,92 & 3,04 & 1,46 & 1,46 & 9,46 \\
\hline PB & 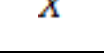 & 1,48 & 2,32 & 2,04 & 0,56 & 0,60 & 7,00 \\
\hline
\end{tabular}

Berdasarkan Tabel 3 di atas, terlihat bahwa dari ketiga indikator kemampuan koneksi matematis yang digunakan, rataan skor postes siswa yang memperoleh 
pembelajaran PS lebih tinggi dari siswa yang memperoleh PB. Namun, pada indikator ke-1 pada soal nomor 2 yaitu indikator menggunakan hubungan antar konsep dan prosedur matematika, persentase pencapaian siswa di kelas PS hanya 20,00\%. Terlihat bahwa kemampuan siswa di kelas PS untuk menggunakan hubungan antar konsep dan prosedur matematika pada soal persamaan trigonometri masih belum optimal. Hal ini dikarenakan pada pembelajaran PS, peneliti memberikan contoh persamaan trigonometri yang dasar pada saat proses pembelajaran.

Selain melihat pencapaian kemampuan koneksi matematis siswa, penelitian ini juga melihat peningkatan kemampuan koneksi matematis siswa yang diamati dari hasil tes siswa sebelum dan setelah diberikan pembelajaran pada masing-masing kelas. Berdasarkan hasil penelitian diperoleh bahwa peningkatan kemampuan koneksi matematis siswa kelas PS lebih baik dari siswa kelas PB. Hal ini dapat dilihat dari rataan skor $N$-gain untuk kelas PS sebesar 0,45 dan kelas PB 0,30 (kategori sedang).

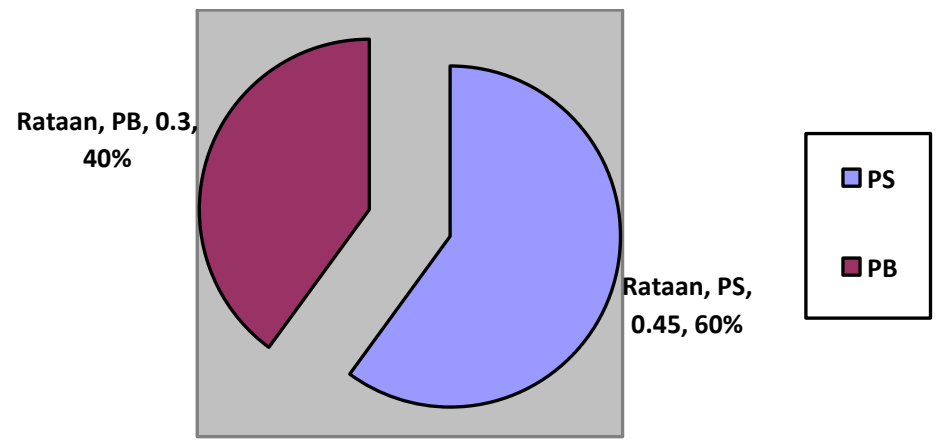

Gambar 2. Rata-rata skor $N$-gain kelas PS dan PB

Selain itu, berdasarkan uji statistik dengan kriteria pengujian yang digunakan yaitu jika nilai sig. $(p$-value $)<\alpha(\alpha=0,05)$, maka $\mathrm{H}_{0}$ ditolak, untuk kondisi lain $\mathrm{H}_{0}$ diterima. Hasil skor $n$-gain kemampuan koneksi matematis siswa dapat dilihat pada tabel berikut.

Tabel 4. Hasil Uji Mann-Whitney Skor N-gain Kemampuan Koneksi Matematis Siswa

\begin{tabular}{ccc}
\hline & $N$-gain & Keputusan \\
\hline $\mathrm{Z}$ & -1.652 & \\
Asym Sig. (2-tailed) & 0.099 & $\mathrm{H}_{0}$ ditolak \\
Asym Sig. (1-tailed) & 0.0495 & \\
\hline
\end{tabular}

Berdasarkan Tabel 4 diketahui bahwa nilai sig. (1-tailed $)=0,0495<\alpha(\alpha=0,05)$, berarti $\mathrm{H}_{0}$ ditolak. Dengan demikian, dapat disimpulkan bahwa peningkatan kemampuan koneksi matematis siswa yang memperoleh pembelajaran PS secara signifikan lebih baik dari siswa yang memperoleh PB.

Lebih baiknya pencapaian dan peningkatan kemampuan koneksi matematis siswa ini disebabkan karena dalam proses pembelajaran PS, siswa dituntut untuk lebih aktif sedangkan guru berperan sebagai fasilitator dalam proses pembelajaran. Tahap pembelajaran PS mengharuskan siswa untuk mampu menghubungkan informasi apa yang diketahui dengan informasi baru yang akan 
disajikan dalam pembelajaran sehingga terjadi pembelajaran yang bermakna. Selain itu, tahap pelaksanaan pembelajaran PS juga memandu siswa untuk melakukan suatu kegiatan dalam proses menemukan suatu konsep serta menyelesaikan permasalahan matematika secara berkelompok dengan metode ilmiah. Kegiatan berkelompok atau diskusi memungkinkan siswa untuk dapat saling berinteraksi satu dengan lainnya, bertanya, mengumpulkan informasi, menyampaikan pendapat, dan menanggapi pendapat siswa lain. Siswa membentuk pengetahuan dan ide-ide baru melalui proses interaksi antar individu yakni bekerjasama dengan guru atau siswa lain yang memiliki kemampuan lebih. Ideide tersebut dikoneksikan dengan materi yang sudah dipelajari sebelumnya baik berupa konsep, definisi, atau aturan sehingga dapat menyelesaikan permasalahan yang diberikan.

Menurut Vygotsky (Mamin, R.,2008), pencapaian siswa dalam menyelesaikan suatu permasalahan dapat berhasil dengan bantuan orang lain (guru, orang tua, atau teman sejawat yang berkemampuan lebih). Jika siswa mengalami kebuntuan dalam menyelesaikan suatu permasalahan atau kurang mengerti terhadap suatu konsep maka siswa dibimbing untuk membangun ide-ide dari apa yang ada dipikirannya. Mereka diarahkan untuk bertanya, mengumpulkan informasi, dan mendiskusikan informasi tersebut dengan kelompoknya. Jika siswa masih mengalami kebuntuan, maka guru mengarahkan siswa dengan memberikan beberapa pertanyaan ransangan, petunjuk, peringatan, dorongan, memberikan contoh soal terkait dengan kemampuan koneksi matematis siswa untuk mengembangkan Zone of Proximal Development (ZPD) yang ada pada diri siswa (Fauzi, 2013). Jika semua permasalahan yang diberikan telah selesai dikerjakan maka barulah siswa mengkomunikasikan atau menyampaikan hasil kerjanya di depan kelas. Ini bertujuan untuk mengevaluasi hasil kerja siswa sehingga guru dapat memberi penegasan dan penguatan terhadap apa yang sudah dipelajari.

\section{Self-Concept}

Berdasarkan hasil analisis pengolahan data self-concept matematis diperoleh bahwa rata-rata skor self-concept siswa kelas yang memperoleh PS lebih tinggi dari siswa yang memperoleh PB. Begitu juga dengan hasil uji statistik yang menunjukkan bahwa self-concept siswa kelas yang memperoleh PS lebih baik dari siswa yang memperoleh pembelajaran biasa. Hal ini dapat dilihat pada tabel berikut.

Tabel 5. Deskripsi Skor Self-concept Matematis Siswa

\begin{tabular}{cccccc}
\hline Kelas & N & Minimum & Maksimum & Mean & SD \\
\hline PS & 24 & 45.00 & 76.00 & 60.38 & 7.01 \\
PB & 25 & 43.00 & 70.00 & 56.60 & 7.24 \\
& & Skor Maksimum Ideal = 85 & & \\
\hline
\end{tabular}

Rataan skor self-concept matematis siswa kelas PS sebesar 60,38 atau $71,02 \%$ dari skor maksimum ideal dan untuk kelas PB sebesar 56,60 atau 66,59\% dari skor maksimum ideal. Terlihat adanya perbedaan rataan skor self-concept matematis siswa pada kedua kelas sebesar 3,78 atau sebesar 4,44\%. Rataan skor self-concept matematis siswa kelas PS lebih tinggi dari siswa kelas PB. Artinya pembelajaran PS memberikan kontribusi yang cukup baik dalam pengembangan 
self-concept matematis siswa jika dibandingkan dengan pembelajaran $\mathrm{PB}$, walaupun dengan perbedaan yang sangat kecil. Namun, perlu dilakukan uji statistik untuk menunjukkan bahwa self-concept kedua kelas berbeda atau tidak secara signifikan.

Mengetahui signifikansi perbedaan rerata self-concept siswa kelas PS dan PB dilakukan uji statistik nonparametrik karena data self-concept yang akan diuji merupakan data ordinal. Kriteria pengujian yang digunakan yaitu jika nilai sig. ( $p$ value $)<\alpha(\alpha=0,05)$, maka $\mathrm{H}_{0}$ ditolak, untuk kondisi lain $\mathrm{H}_{0}$ diterima. Hasil rangkuman uji perbedaan rataan disajikan pada tabel berikut.

Tabel 6. Hasil Uji Mann-Whitney Skor Self-concept Matematis Siswa

\begin{tabular}{ccc}
\hline & Self-concept & Keputusan \\
\hline Z & -1.663 & \\
Asym Sig. (2-tailed) & 0.096 & $\mathrm{H}_{0}$ ditolak \\
Asym Sig. (1-tailed) & 0.048 & \\
\hline
\end{tabular}

Berdasarkan Tabel 6 diketahui bahwa nilai sig. (1-tailed) $=0,048<\alpha(\alpha=0,05)$, berarti $\mathrm{H}_{0}$ ditolak. Dengan demikian, dapat disimpulkan bahwa self-concept matematis siswa yang memperoleh pembelajaran PS secara signifikan lebih baik dari siswa yang memperoleh PB.

Lebih baiknya self-concept siswa kelas PS dari self-concept siswa kelas PB ini disebabkan karena PS sangat memungkinkan untuk mengaktifkan siswa dalam kegiatan pembelajaran. Siswa dilatih untuk mampu berkolaborasi dengan teman sekelompoknya mendiskusikan berbagai masalah dan kegiatan yang berkaitan dengan topik pembelajaran, membangun ide-ide serta membuat dugaan untuk menyelesaikan suatu permasalahan matematika. Dalam tahap tersebut, siswa dilatih untuk dapat percaya diri mengungkapkan apa yang dipikirkannya mengenai definisi atau konsep yang diajarkan. Kemudian, siswa diberikan kesempatan mengkomunikasikan hasil diskusinya. Ahmad, J., Ghazali, M., \& Hasan, A., (2011); Srivastava, R., \& Joshi, S., (2014); dan Sumartini, T. S., (2015) menyatakan bahwa kolaborasi dengan teman sekelompok dalam hal menggabungkan ide-ide atau dugaan dari konsep atau definisi yang dipelajari dapat melatih siswa untuk menumbuhkan self-concept positif siswa. Keluesan pengetahuan siswa mengakibatkan rasa percaya diri yang tinggi selama mengikuti proses pembelajaran (Abidin, 2013). Rasa percaya diri sangat penting terhadap self-concept positif mereka agar berani melakukan berbagai aktivitas belajar dan terbiasa menanggung resiko pembelajaran. Hal ini menunjukkan bahwa selfconcept yang positif dapat dibentuk dengan baik jika kita menggunakan PS sebagai salah satu bentuk strategi pembelajaran.

\section{KESIMPULAN DAN SARAN}

Berdasarkan penelitian yang dilakukan, maka diperoleh kesimpulan terdapat pencapaian dan peningkatan kemampuan koneksi dan self-concept matematis yang lebih baik dengan menggunakan pendekatan saintifik daripada pembelajaran biasa. Siswa menyelesaikan permasalahan matematika secara berkelompok dengan metode ilmiah. Adapun tahap pelaksanaan pembelajaran dengan menggunakan pedekatan saintifik meliputi: 1) siswa mengamati kegiatan atau suatu permasalahan yang diberikan oleh guru dan melakukan proses tanya 
jawab terkait hal-hal yang diamati dan dicermati; 2) siswa mengumpulkan informasi dari permasalahan yang diberikan serta berbagai buku sumber yang ada dan menemukan ide (mengkoneksikan konsep terkait) untuk menyelesaikan soal atau masalah yang diberikan; 3) siswa menghubungkan konsep materi yang dipelajari dan menganalisis permasalahan secara berkelompok maupun individu melalui bimbingan guru; 4) guru meminta siswa untuk mempresentasikan atau mengomunikasikan hasil penyelesaian masalah; dan 5) siswa melakukan evaluasi terhadap hasil presentasi dan membuat rangkuman materi yang sudah dipelajari.

Beberapa saran yang dapat dijadikan pertimbangan semua pihak untuk menerapkan pendekatan saintifik dalam pembelajaran matematika antara lain; 1) masih diperlukan usaha agar peningkatan kemampuan koneksi matematis siswa dapat mencapai kategori tinggi seperti mempertimbangkan penambahan waktu pada tahap pengumpulan data karena pada tahap ini siswa dilatih untuk mengumpulkan ide-ide yang diperolehnya untuk menyelesaikan permasalahan matematika; 2) persentase pencapaian siswa dalam hal menghubungkan antar konsep atau prosedur matematika pada materi persamaan trigonometri masih lemah yaitu hanya $20 \%$. Oleh sebab itu, disarankan bagi yang ingin melanjutkan penelitian ini agar dapat memberikan contoh yang lebih kompleks mengenai materi persamaan trigonometri; 3) pendekatan saintifik hendaknya dapat dicoba sebagai alternatif pembelajaran di sekolah terutama dalam pembelajaran topik tertentu, yaitu topik baru yang berkaitan dengan topik sebelumnya yang sudah dipelajari siswa sehingga siswa lebih bermakna dalam belajar dan mampu mengkoneksikan pengetahuan yang diperolehnya serta kritis dalam memikirkan penyelesaian dari persoalan matematika yang diberikan; 4) pengetahuan awal siswa terhadap materi prasyarat memiliki peran penting terhadap kemampuan siswa dalam menguasai dan mengkoneksikan konsep yang dipelajarinya. Oleh sebab itu, sebelum konsep atau informasi baru diberikan hendaknya terlebih dahulu dilakukan apersepsi atau penguatan konsep prasyarat siswa sehingga dapat membantu siswa dalam menjelaskan pemikirannya.

\section{DAFTAR RUJUKAN}

Abidin, Y. (2013). Desain Sistem Pembelajaran dalam Konteks Kurikulum 2013. Bandung: Refika Aditama.

Ahmad, J., Ghazali, M., \& Hasan, A. (2011). The Relationship Between Self Concept and Response Toward Student's Academic Achievement Among Students Leader in niversity Putra Malaysia. International Journal of Instruction. July 2011, Vol. 4, No. 2, e-ISSN: 1308 - 1470. www.e-iji.net, p- ISSN: $1694-609 X$.

Arikunto, S. (2013). Prosedur Penelitian. Jakarta: Rineka Cipta.

Atsnan , M. F dan Gazali, Y. R. (2013). Penerapan Pendekatan Scientific dalam Pembelajaran MAtematika SMP Kelas VII Materi Bilangan (Pecahan) . Jurnal Pendidikan Matematika Pascasarjana UNY.

Ayodele, J.O. (2011). Self Concept and Performance of Secondary school Students in Mathematics. Journal of Educational and Developmental Psychology, 1 (1); 49-54.

Efriana, F. (2014). Penerapan Pendekatan Scientific untuk Meningkatkan Hasil Belajar Siswa Kelas VII MTsN Palu Barat pada Materi Keliling dan Luas Daerah Layang-layang. Jurnal Elektronik Pendidikan Matematika 
Tadulako, Vol. 1, No. 2, Maret 2014.

Fajri, Nurul, Hajidin, \& Ikhsan, M. (2014). Peningkatan Kemampuan Koneksi \& Komunikasi Matematis Siswa dengan Menggunakan pendekatan Contextual Teaching and Learning (CTL). Jurnal Pendididikan Matematika, PARA DIKMA, Vol. 6, No.2, hal 149 - 161.

Fauzi, K. M. A. (2013). Kemampuan Koneksi Matematis Siswa dengan Pendekatan Pembelajaran Metakognitif di Sekolah Menengah Pertama. Jurnal Pendidikan Maematika PARADIKMA, Vol. 6. No. 1, hal 49 - 74.

Hendriana, H., Slamet, U.R., dan Sumarmo, U. (2014). Mathematical Connection Ability an Self-Confidence (An Experiment On Junior High School Students Through Contextual Teaching and Learning with Mathematical Manipulative). International Journal of Education. Vol. 8. No. 1 December 2014.

Kemendikbud. (2013). Materi Pelatihan Implementasi Kurikulum 2013. Jakarta: Kementerian Pendidikan dan Kebudayaan.

Komala, E. (2012). Pembelajaran dengan Pendekatan Diskursif untuk Meningkatkan Kemampuan Pemecahan Masalah Matematis dan SelfConcept Siswa SMP. Tesis SPs UPI Bandung: tidak diterbitkan.

Kuhlthau, C. C., Maniotes, L. K dan Capari, A. K. (2007). Guide Inquiry: Learning in the Zist Century. London: Libraries Unlimited.

Kusmaydi. (2010). Pembelajaran Matematika Realistik untuk Meningkatkan Kemampuan Komunikasi dan Pemecahan Masalah Matematis Siswa SMP. Tesis SPs UPI Bandung: tidak diterbitkan.

Lasmanawati. (2011). Pengaruh Pembelajaran Menggunakan Pendekatan Proses Berpikir Reflektif terhadap Peningkatan Kemampuan Koneksi dan Berpikir Kritis Matematis Siswa. Tesis SPS UPI. Bandung: tidak diterbitkan.

Leonard dan Supardi, U.S. (2010). Pengaruh Konsep Diri, Sikap Siswa pada Matematika dan Kecemasan Siswa terhadap Hasil Belajar Matematika. Cakrawala Pendidikan: FT dan FMIPA Universitas Indraprasta PGRI.

Linto, R L., Elniati, S., \& Rizal, Y. (2012). Kemampuan Koneksi Matematis dan Metode Pembelajaran Quantum Teaching dengan Peta Pikiran. Jurnal Pendidikan Matematika Vol. 1, No. 1, 83-87.

Mamin, R. (2008). Penerapan Metode Pembelajaran Scaffolding pada pokok Bahasan Sistem Periodik Unsur. Jurnal Chemica Vol. 10, No. 2, Desember 2008, 55-60.

Marjan, J., Arnyana, I. B. P., dan Setiawan, I. G. A. N. (2014). Pengaruh Pembelajaran Pendekatan Saintifik terhadap Hasil Belajar Biologi dan Keterampilan Proses Sains Siswa MA Mu'allimat NW Pancor Selong Kabupaten Lombok Timur Nusa tenggara Barat. E-journal Program Studi Pascasarjana Universitas Pendidikan Ganesjha Program Studi IPA Vol. 4, 2014.

NCTM. (2000). Principles and Standards for School Mathematics. Reston, Virginia.

Nurhajati. (2014). Pengaruh Penerapan Pendekatan Konstruktivisme dengan Model Pembelajaran Kooperatif Berbantuan Program Cabri 3D terhadap Kemampuan Penalaran dan Koneksi Matematis Siswa SMA di Kota Tasikmalaya. Jurnal Pendidikan dan Keguruan Vol.1 , No. 1, 2014. 
Pardede, Y. O. K. (2008). Konsep Diri Anak Jalanan Usia Remaja, Jurnal Psikologi, Vol. 1, No. 2, Juni 2008 Fakultas Psikologi Universitas Gunadarma.

Permana, Y. dan Sumarmo, U. (2007). Mengembangkan Kemampuan Penalaran \& Koneksi Matematika Siswa SMA melalui Pembelajaran Berbasis Masalah. Jurnal Educationist Vol. I. No. 2 Juli 2007, ISBN: 1907 - 8838.

Prahastiwi, R. B., Subani, \& Haryoto, D. (2014). Penerapan Pendekatan Saintifik untuk Meningkatkan Karakter Rasa Ingin Tahu dan Prestasi Belajar Siswa Kelas X MIA 3 SMA Negeri 6 Malang. Jurnal online UM [http://jurnalonline.um.ac.id/data/artikel/artikel7F8AE3439383C8E200DCFEED3490E 16B.pdf].

Rahmatudin, J., Hidayat, A., Shabiqoh, K. (2014). Penerapan Pendekatan Saintifik dalam Upaya Meningkatkan Kemampuan Penalaran Matematis Siswa SMP. Jurnal Integral Edisi 7 Volume 1 Tahun 2016, 21 - 31.

Salamor, R. (2013). Pembelajaran Group Investigation dalam Upaya Peningkatan Kemampuan berpikir Kritis dan Self Concept Matematis Siswa Sekolah Menengah Pertama. Tesis SPs UPI Bandung: tidak diterbitkan.

Silvernail, D. (1985). Developing Positive Student Self-concept. Second Edition. Washington DC: National Education Associatess.

Srivastava, Rekha, \& Joshi, Shobhna. (2014). Relationship Between Self-Concept and Self-Esteem in Adolescents. International Journal of Advanced Research Vol. 2. Issue 2, 36 - 43.

Sumarmo, U. (2010). Berpikir dan Disposisi Matematis serta Budi Pekerti dalam Pembelajaran Matematika. Hand-out Seminar Pendidikan Matematika. Yogyakarta: tidak diterbitkan.

Sumartini, Tina Sri (2015). Mengembangkan Self-Concept Siswa Melalui Model Pembelajaran Concept Attaiment. Jurnal Pendidikan Matematika,Vol. 5, No. 2, April 2015. ISSN: 2086. 4299.

Suherman, E. et al. (2003). Strategi Pembelajaran Matematika Kontemporer Common Texbook (Edisi Revisi). Bandung: JICA UPI.

Suherman, E. (2008). Belajar dan Pembelajaran Matematika. Hand-out Perkuliahan Pendidikan Matematika FPMIPA UPI Bandung: tidak diterbitkan. 